\title{
PYRUVATE KINASE IN MUSCLE EXTRACTS OF THE SEA MUSSEL MYTILUS EDULIS L.
}

\author{
ALBERTUS DE ZWAAN \\ Laboratory of Chemical Animal Physiology, State University of Utrecht, The Netherlands
}

(Received 18 October 1971)

\begin{abstract}
Pyruvate kinase activity in fresh extracts from the posterior adductor muscle of the sea mussel, Mytilus edulis, shows allosteric properties in contrast to skeletal pyruvate kinases of mammals.

2. The Hill plot at $[\mathrm{PEP}]^{*}=\infty$ shows positive co-operativity $\left(n_{\mathrm{H}}=1 \cdot 3\right)$ with respect to PEP.

3. The sigmoidicity of the substrate concentration-velocity curve is strongly increased in the presence of alanine (inhibition). The Hill coefficient increases from 1.3 to 1.8 whereas the $K_{m}$ app. for PEP changes from 0.65 to $1.58 \mathrm{mM}$.

4. Pyruvate kinase activity is also strongly inhibited by ATP.

5. Inhibition of pyruvate kinase activity by alanine and ATP is counteracted by FDP.

6. The properties of pyruvate kinase might explain why a part of PEP is available for succinate production during anaerobic glycolysis.
\end{abstract}

\section{INTRODUCTION}

STUDies on pyruvate kinases are mainly restricted to yeast (Haeckel et al., 1968) and various mammalian tissues such as rat liver (Tanaka et al., 1967; Bailey et al., 1968) and human erythrocytes (Cartier et al., 1968; Staal et al., 1971). There are two main types of this enzyme : type $L$ and type $M$, indicating which type dominates in rat liver and muscle respectively (Tanaka et al., 1967). The $L$ type shows a sigmoidal relationship between PEP concentrations and reaction velocity. FDP activates the enzyme by raising the affinity for PEP. Type $M$ shows simple hyperbolic substrate kinetics and FDP has no influence on this type.

The M type is widely distributed in various tissues, whereas the "allosteric" $L$ type is mainly present in gluconeogenic tissues such as liver and kidney cortex (Llorente et al., 1970).

This paper presents evidence showing that pyruvate kinase in the muscle tissue of the common sea mussel, Mytilus edulis, possesses kinetic properties which

*'The following abbreviations are used: PEP, phosphoenolpyruvate; $n_{\mathrm{H}}$, Hill coefficient; $K_{m}$, Michaelis constant; ATP, adenosine triphosphate; FDP, fructose diphosphate; ADP, adenosine diphosphate; NADH, nicotinamide adenine dinucleotide, reduced form; LDH, lactate dehydrogenase; PK, pyruvate kinase; PEP-CK, phosphoenolpyruvate carboxykinase; HK, hexokinase; Glc, glucose; MAP, $\mathrm{m}$. adductor posterior; ALA, alanine; $\mathrm{U}=$ enzyme unit ( $\mu$ mole product formed/min per $\mathrm{mg}$ protein), app. = apparent. 
are similar to that of the L-type in rat liver. These properties are homotropic co-operativity with respect to PEP, strong activation by FDP and strong allosteric inhibition by alanine. This is in sharp contrast with pyruvate kinase in skeletal muscle (Boyer, 1962). Enzyme activity is also inhibited by ATP.

\section{MATERIALS AND METHODS}

All reagents and chemicals were of analytical grade. Mussels were collected from a natural bed in the Waddenzee. Animals $5.5 \pm 0.2 \mathrm{~cm}$ in length were selected. Posterior adductor muscles of about three mussels were pooled, cooled in ice, weighed (ca. $1 \mathrm{~g}$ ) and cut into small pieces before being homogenized in a Potter-Elvehjem homogenizer $(1 \mathrm{~g}$ wet tissue $/ 10 \mathrm{ml}$ homogenizing medium). The homogenizing medium consisted of $0.15 \mathrm{M}$ $\mathrm{KCl}$ with $8 \%(\mathrm{v} / \mathrm{v}) 0.02 \mathrm{M} \mathrm{KHCO}_{3}$. The homogenate was centrifuged at $3000 \mathrm{~g}$ for $20 \mathrm{~min}$ and the supernatant fraction was spun again at $105,000 \mathrm{~g}$ for $40 \mathrm{~min}$ at $0^{\circ} \mathrm{C}$. The clear supernatant was used for the enzymatic assay.

Pyruvate kinase activities were measured spectrophotometrically at $340 \mathrm{~nm}$ and $25^{\circ} \mathrm{C}$ by coupling the system with excess lactate dehydrogenase, according to the method of Bücher \& Pfleiderer (1955). All experiments were carried out in $100 \mathrm{mM}$ imidazole-buffer $(\mathrm{pH}=7.4), 67 \mathrm{mM} \mathrm{KCl}, 8.3 \mathrm{mM} \mathrm{MgSO}$, $5.0 \mathrm{mM}$ ADP, $0.067 \mathrm{mM} \mathrm{NADH}, 36 \mathrm{U}$ LDH and PEP concentrations as indicated below in a final volume of $3 \mathrm{ml}$. Each assay was performed with $100-300 \mu \mathrm{g}$ of protein. The reaction was started by adding PEP after the enzyme extract was preincubated for $10 \mathrm{~min}$ at $25^{\circ} \mathrm{C}$.

PEP-carboxykinase activities were measured spectrophotometrically at $340 \mathrm{~nm}$ and $25^{\circ} \mathrm{C}$ by coupling the system with excess malate dehydrogenase, according to the method of Utter \& Kurahashi (1954).

To determine concentrations of FDP, PEP, alanine and succinate, the soft parts of the mussel were cut into small pieces with scissors, homogenized in a Potter-Elvehjem homogenizer with an equal volume of $6 \%(\mathrm{v} / \mathrm{v})$ perchloric acid and centrifuged at $13,000 \mathrm{~g}$. The supernatant was neutralized with a solution of $5 \mathrm{~N} \mathrm{KOH}$ and cooled in a refrigerator for a few hours. The precipitated $\mathrm{KClO}_{4}$ was removed by centrifugation and the clear supernatant was used. FDP, PEP and alanine were determined according to procedures described by Bücher \& Hohorst (1965), Czok \& Eckert (1965) and Pfleiderer (1965) respectively. Concentrations of succinate were assayed as described by Kmetec (1966) using Ascaris succinate dehydrogenase.

Protein was determined by the method of Lowry et al. (1951).

\section{RESULTS}

Figure 1 shows the substrate concentration-velocity curves in the presence and absence of modulating substrates (FDP or alanine). When absent there is an atypical dependence of reaction velocity on substrate concentration (non-MichaelisMenten relationship). This is reflected in a slight sigmoidicity of the saturation curve, while the Lineweaver-Burk plot shows a curve concave upwards. The Hill plot (Fig. 2) at (ADP) $=\infty$ shows positive co-operativity $\left(n_{\mathrm{H}}=1 \cdot 3\right)$ with respect to PEP, whereas a $K_{m}$ app. of $0.65 \mathrm{mM}$ for PEP could be calculated (concentration of PEP when $\left.\log \left[v /\left(V_{\max }-v\right)\right]=0\right)$. The sigmoidicity is strongly increased in the presence of $2.0 \mathrm{mM}$ alanine, resulting in an almost total inhibition of the reaction velocity at physiological concentrations of PEP $(0.13 \pm 0.04 \mu \mathrm{mole} / \mathrm{g}$ wet tissue $\infty 0.1 \mathrm{mM}$ PEP). The Hill coefficient $n_{\mathrm{H}}$ increases from 1.3 to 1.8 whereas the 

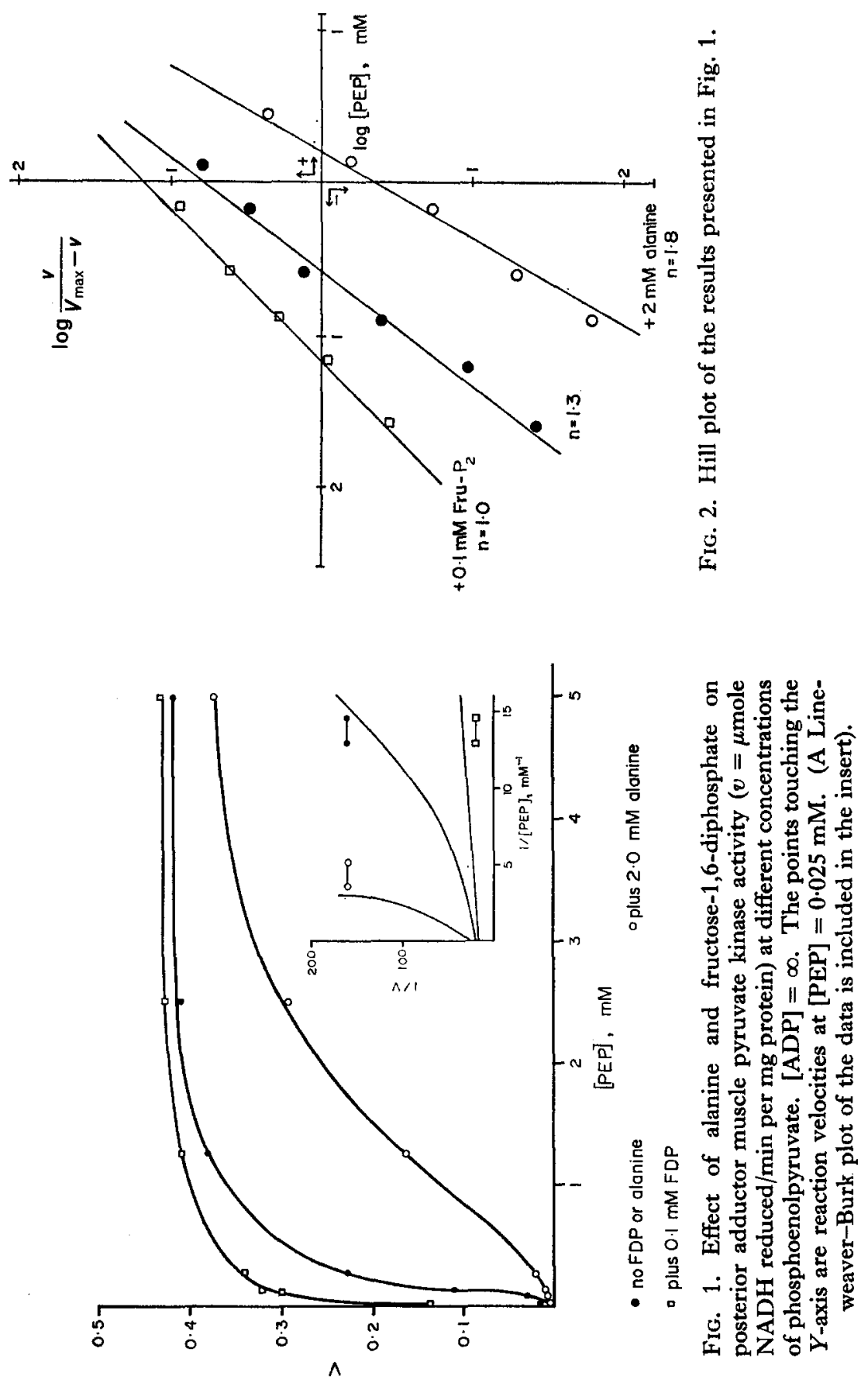
$K_{m}$ app. for PEP changes from 0.65 to $1.58 \mathrm{mM}$ (Fig. 2). At the high concentrations of PEP used to provide optimum levels of pyruvate kinase activity, alanine has almost no inhibiting effect. The nature of alanine inhibition seems to resemble that as described for pyruvate kinase in rat liver (Weber et al., 1968).

Addition of $0.1 \mathrm{mM}$ FDP shifts the kinetics from sigmoid to hyperbolic, showing a straight line on the Lineweaver-Burk plot. The Hill coefficient is 1 , whereas the $K_{m}$ app. for PEP becomes $0.25 \mathrm{mM}$ (Fig. 2). At physiological concentrations of PEP of around $0.1 \mathrm{mM}$ there is an activation of pyruvate kinase reaction velocity of about six times (Figs. 1 and 3 ).

Figure 3 shows that the affinity of pyruvate kinase for FDP is much greater than for alanine. Inhibition of alanine up to $10 \mathrm{mM}$ is almost completely counteracted by $0.1 \mathrm{mM} F D P$ at $[\mathrm{PEP}]=0.25$ and about 70 per cent at $[\mathrm{PEP}]=0.10 \mathrm{mM}$.

Figure 4 shows inhibition of pyruvate kinase activity by ATP. ATP is a less effective inhibitor than alanine. Half inhibition of reaction velocity at $[\mathrm{PEP}]=$ $0.25 \mathrm{mM}$ is reached when the concentration of ATP is about $2.5 \mathrm{mM}$, compared to $0.2 \mathrm{mM}$ for alanine.

Table 1 shows that ATP and alanine inhibition are independent of each other. When both are added to the reaction mixture, the overall inhibition is equal to the sum of their individual effects. When ATP inhibition is counteracted by the addition of glucose and hexokinase, the resulting activity is equal to a test medium containing only alanine.

Table 1-Inhibition of pyruvate kinase activity by alanine and ATP and alanine PLUS ATP. $[\mathrm{PEP}]=0.25 \mathrm{mM}$

\begin{tabular}{|c|c|c|c|}
\hline No. & $\begin{array}{l}\text { Added } \\
\text { substrates }\end{array}$ & $\begin{array}{c}\mu \text { mole NADH } \\
\text { oxidized } / \mathrm{min} \\
\text { per } \mathrm{mg} \\
\text { protein }\end{array}$ & $\begin{array}{c}\text { Percentage of } \\
\text { activity at } \\
\mathrm{PEP}=0.25 \mathrm{mM}\end{array}$ \\
\hline 1 & None & $0 \cdot 200$ & 100 \\
\hline 2 & $0.2 \mathrm{mM}$ ALA & $0 \cdot 145$ & $72 \cdot 5$ \\
\hline 3 & $2 \cdot 0 \mathrm{mM}$ ATP & $0 \cdot 124$ & 62 \\
\hline 4 & $0.2 \mathrm{mM} \mathrm{ALA}+2.0 \mathrm{mM}$ ATP & $0 \cdot 088$ & 44 \\
\hline 5 & $\begin{array}{l}0.2 \mathrm{mM} \mathrm{ALA}+2.0 \mathrm{mM} \mathrm{ATP} \\
+3 \mathrm{mM} \mathrm{Glc}+16 \mathrm{U} \mathrm{HK}\end{array}$ & $0 \cdot 148$ & 74 \\
\hline 6 & $\begin{array}{l}0.2 \mathrm{mM} \mathrm{ALA}+2.0 \mathrm{mM} \text { ATP } \\
+0.1 \mathrm{mM} \mathrm{FDP}\end{array}$ & $0 \cdot 267$ & $133 \cdot 5$ \\
\hline
\end{tabular}

\section{DISCUSSION}

The allosteric properties of pyruvate kinase in muscle tissue of the sea mussel are in strong contrast to pyruvate kinase in skeletal muscle (Boyer, 1962). This is probably of physiological significance, because the enzyme PEP-carboxykinase is also present in the posterior adductor muscle with relatively high activity as shown 

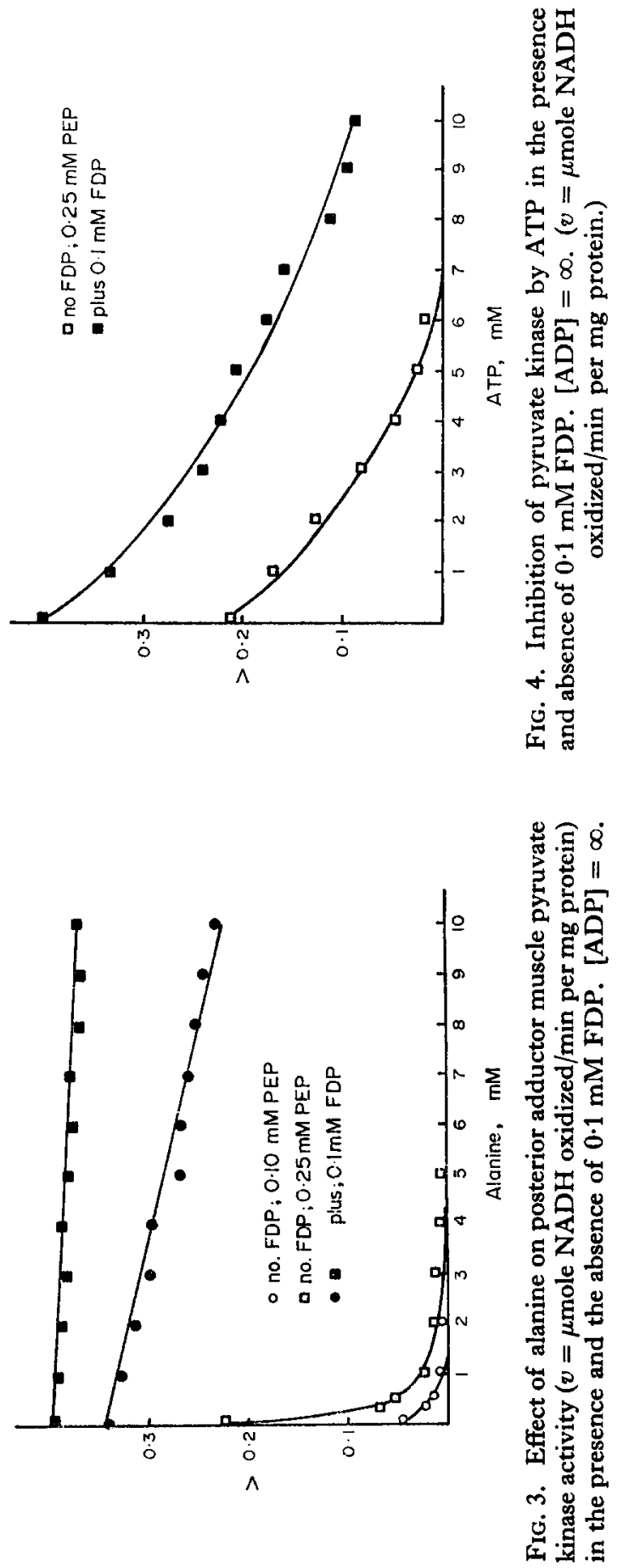
in Table 2, whereas in rat this enzyme is more or less restricted to liver and kidney (Scrutton \& Utter, 1968).

Table 2-Specific activities ( $\mu$ mole NADH oxidized/min per mg protein) of PYruvate KINASE AND PEP-CARBOXYKINASE IN VARIOUS TISSUES OF THE SEA MUSSEL, COMPARED TO THE RAT

\begin{tabular}{lcccc}
\hline & \multicolumn{4}{c}{ Mussel } \\
\cline { 2 - 5 } & MAP & Digestive gland & Mantle & Gill \\
\hline PEP-CK & $278 \pm 21$ & $56 \pm 3$ & $102 \pm 10$ & $112 \pm 12$ \\
PK & $369 \pm 21$ & $221 \pm 4$ & $492 \pm 19$ & $241 \pm 7$ \\
& & \multicolumn{2}{c}{ Rat* } \\
\cline { 2 - 4 } & & Skeletal muscle & Liver \\
\cline { 2 - 4 } & PEP-CK & 0.5 & $33 \cdot 5$ \\
& PK & 3900 & 250 \\
\hline
\end{tabular}

*After Scrutton \& Utter (1968).

These differences are reflected in PEP disposition during carbohydrate breakdown under anaerobic conditions; the mussel transforms PEP partly into succinate via malate, fumarate and oxalacetate by $\mathrm{CO}_{2}$ fixation (de $Z$ waan, 1971), whereas in skeletal muscle PEP is catalysed towards L-lactate under such conditions. At least in the bivalves $M$. edulis (de Zwaan, 1971) and Rangia cuneata (Stokes \& Awapara, 1968 ) the remaining PEP becomes mainly transformed into alanine via pyruvate, whereas only small amounts of lactate are produced.

Bueding \& Saz (1968) established the steady-state concentrations of pyruvate and oxalacetate by measuring the activity of pyruvate kinase and PEP-carboxykinase. They concluded for three species of parasitic worms that the ratio of these enzyme activities determine the amount of the end product, lactate and/or succinate. For the sea mussel this would mean that most of the available PEP is transformed into pyruvate (Table 2). But after a period of $48 \mathrm{hr}$ of shell closure, alanine and succinate were accumulated in almost equimolar amounts (de Zwaan, 1971). Therefore PEP must be divided equally between pyruvate and oxalacetate.

The described properties of pyruvate kinase in glycolytic muscle tissue of the sea mussel might explain why a part of PEP is available for succinate production, by proposing that the affinity of PEP for pyruvate kinase is diminished as a result of feedback inhibition by alanine and ATP.

To understand the physiological significance of the presented results, the normal concentrations of FDP, alanine and PEP were determined as well as those influenced by anaerobiosis (Table 3 ). 


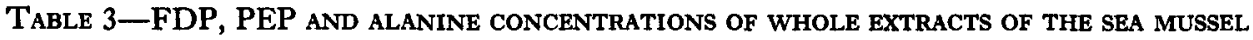

\begin{tabular}{ccrc}
\hline Group & FDP* & PEP* & ALA ${ }^{*}$ \\
\hline I & $18 \pm 4$ & $13 \pm 4$ & $586 \pm 220$ \\
II & $11 \pm 8$ & $8 \pm 7$ & $918 \pm 223$ \\
\hline
\end{tabular}

Group I was analysed immediately after collecting from the sea. Group II was previously kept dry for $48 \mathrm{hr}$.

*Average value of nine samples.

†Average value of fifteen samples.

All figures express $10^{-2} \mu$ mole/g wet weight of tissue.

Within the range of physiological concentrations of PEP and alanine the activity of pyruvate kinase would be negligible without FDP (Fig. 3). As a consequence of $48 \mathrm{hr}$ of shell closure the concentration of alanine rises to about $10 \mathrm{mM}$, whereas concentrations of PEP and FDP seem to decrease. From Table 3 and Fig. 3 it is clear that pyruvate kinase activity becomes reduced to about 70 per cent under conditions of $48 \mathrm{hr}$ of shell closure as a result of alanine accumulation (Fig. 3 ).

No data are available about the normal concentrations of ATP in the mussel. By comparing with mammalian tissue which is in the order of 2-3 mM (Bücher et al., 1964) it seems reasonable to suppose from Fig. 4 that ATP can have some inhibitory effect on pyruvate kinase.

Succinate, tested in a range of $0.1-2.0 \mathrm{mM}$ did not show any effect on the reaction velocity of pyruvate kinase.

Acknowledgements-The author is grateful to Professor Dr. D. I. Zandee for his guidance and valuable criticism.

\section{REFERENCES}

Bailey E., Stirpe F. \& TaYler C. B. (1968) Regulation of rat liver pyruvate kinase. Biochem. $\mathcal{F} .108,427-437$.

BoYer P. D. (1962) Pyruvate kinase. In The Enzymes (Edited by BoYer P. D., LARDY H. \& MyraAck K.), Vol. 6, p. 95. Academic Press, New York.

BÜChER T. \& HoHORST H. J. (1965) Dihydroxyacetone phosphate, fructose-1,6-diphosphate and D-glyceraldehyde-3-phosphate. Determination with glycerol-1-phosphate dehydrogenase, aldolase and triose phosphate isomerase. In Methods of Enzymatic Analysis (Edited by BergmeYer H. U.), p. 246. Academic Press, New York.

Bücher T., Krejci K., Rưssmann W., Schnitger H. \& Wessemann W. (1964) Metabolite assay in frozen samples of liver tissue. In Rapid Mixing and Sampling Techniques in Biochemistry (Edited by Chance B., Eisenhardt R. H., Gibson Q. H. \& LonberGHolm K. K.), p. 225. Academic Press, New York.

Bucher T. \& Pfleiderer G. (1955) Pyruvate kinase. In Methods in Enzymology (Edited by Colowick S. P. \& Kaplan N. O.), Vol. I, pp. 435-436. Academic Press, New York.

Bueding E. \& SAZ H. J. (1968) Pyruvate kinase and phosphoenolpyruvate carboxykinase activities of Ascaris muscle, Hymenolepis diminuta and Schistosoma mansoni. Comp. Biochem. Physiol. 24, 511-518. 
Cartier P., Najman A., Leroux, J. P. \& Temkine H. (1968) Les anomalies de la glycolyse au cours de l'anémie hémolytique par déficit du globule rouge en pyruvate kinase. Clin. chim. Acta 22, 165-181.

CzoK R. \& EckerT L. (1965) D-3-Phosphoglycerate, D-2-phosphoglycerate, phosphoenolpyruvate. In Methods of Enzymatic Analysis (Edited by BergmeYer H. U.), p. 224. Academic Press, New York.

Haeckel R., Hess B., Lautekborn W. \& Wüster K. H. (1968) Purification and allosteric properties of yeast pyruvate kinase. Hoppe-Seyler's Z. physiol. Chem. 349, 699-714.

KMETEC E. (1966) Spectrophotometric method for the enzymatic micro-determination of succinic acid. Analyt. Biochem. 16, 474-480.

Llorente P., Marco R. \& Sols A. (1970) Regulation of liver pyruvate kinase and the phosphoenolpyruvate crossroads. Eur. F. Biochem. 13, 45-54.

Lowry O. H., Rosebrough N. H., Farr A. L. \& Randall R. J. (1951) Protein measurement with the Folin phenol reagent. F. biol. Chem. 193, 265-275.

PFLEIDERER G. (1965) L-Alanine. Determination with glutamate-pyruvate transaminase and lactic dehydrogenase. In Methods in Enzymatic Analysis (Edited by BERGMEYER H. U.), p. 378. Academic Press, New York.

SCRUTTON M. C. \& UTTER F. M. (1968) The regulation of glycolysis and gluconeogenesis in animal tissues. A. Rev. Biochem. 37, 249-297.

Staal G. E. J., Koster J. F., Kamp H., van Milligen-Boersma L. \& Veeger C. (1971) Human erythrocyte pyruvate kinase. Its purification and some properties. Biochim. biophys. Acta 227, 86-96.

Stokes T. \& Awapara J. (1968) Alanine and succinate as end-products of glucose degradation in the clam Rangia cuneata. Comp. Biochem. Physiol. 25, 883-892.

Tanaka T., Harano Y., Sue F. \& Morimura H. (1967) Crystallization, characterization and metabolic regulation of two types of pyruvate kinase isolated from rat tissues. F. Biochem. (Tokyo) 62, 71-91.

UtTer M. F. \& KuRAhashi K. (1954) Mechanism of action of oxalacetic carboxylase. $\mathcal{f}$. biol. Chem. 207, 821-841.

Weber G., Lea M. A. \& Stamm N. B. (1968) Sequential feedback inhibition and regulation of liver carbohydrate metabolism through control of enzyme activity. Adv. Enzyme Reg. 6, 101-123.

DE ZWAAN A. (1971) The anaerobic carbohydrate metabolism in the sea mussel Mytilus edulis L. Thesis, Utrecht University.

Key Word Index-Mytilus edulis; carbohydrate metabolism; anaerobiosis; pyruvate kinase; enzyme regulation. 